\title{
Transisi Penyerapan Tenaga Kerja Sektoral di Indonesia
}

\section{Ecces: \\ Economics Social and Development Studies}

\author{
Intan Lestari, \\ M. Pudjihardjo, \\ Devanto Shasta Pratomo.
}

Fakultas Ekonomi dan Bisnis Universitas Brawijaya, Malang, Indonesia.

Email: intaniswift@gmail.com

(Article history) Received: 2020-04-20, Revised: 2020-04-29, Accepted: 2020-06-05, Available online: 2020-06-20 DOI: 10.24252/ecc.v7i1.13491

\section{Abstrak: Transisi Penyerapan Tenaga Kerja Sektoral di Indonesia}

Penelitian ini menjelaskan adanya kondisi Indonesia yang mengalami transisi penyerapan tenaga kerja menuju industrialisasi secara sektoral. Dengan menggunakan Survei Angkatan Kerja Nasional (Sakernas), penelitian ini melihat keadaan sebelumnya dari pekerja yang dipekerjakan untuk mengetahui transisi pekerjaan sektoral. Dengan model multinomial logit, penelitian ini menggunakan variabel transisi dilengkapi dengan karakteristik lain yang mempengaruhi penyerapan tenaga kerja sektoral. Hasil temuan ini menjelaskan bahwa transisi sektoral yang memiliki peluang besar mengarah pada sektor industri dan jasa yang menjelaskan peran disrupsi ekonomi yang besar terhadap perubahan. Tidak hanya transisi di sektor lain, studi ini juga menunjukkan bahwa besarnya kemungkinan pekerja memilih untuk tetap berada di sektor yang sama sesuai dengan perspektif mereka sendiri. Dari keseluruhan transisi antar sektor, sektor pertanian memiliki nilai penyerapan tenaga kerja terkecil dibandingkan sektor lainnya dan sektor industri merupakan sektor yang paling diminati dibandingkan dengan sektor jasa. Dengan hasil temuan ini, pemerintah sebaiknya mendorong peningkatan dalam sektor pertanian melalui kemajuan pada sektor non pertanian dengan tujuan meningkatkan nilai tambah bagi sektor pertanian.

Kata kunci: Disrupsi Ekonomi, Industri, Jasa, Pertanian, Transisi Sektoral.

\section{Abstract: Sectoral Labor Absorption Transitions in Indonesia}

This study provides evidence on the sectoral transition aimed industrialisation that supported by economic disruptive in Indonesia. Using the National Labor Force Survey (NLFS), allowing for necessarily to track the previous state of the workers employed to know the sectoral job transition. By using multinomial logit model, this study uses transition variable completed with other characteristics that affect sectoral labor absorption. The study finds that the sectoral 
transition that has greatest opportunity leads to the industrial and service sectors which explains the role of large economic disruption to shifts. Not only the transition in other sectors, this study also shows that the magnitude possibilities of workers choosing to remain in the same sector according to their own perspective. Of the overall transition between sectors, the agricultural sector has the smallest value of labor absorption than another sector. With these findings, the government should encourage improvements agricultural sector through advances in the nonagricultural sector by aiming to increase added value for the agricultural sector.

Keyword: Economic Disruption, Industrial, Services, Agriculture, Sectoral Transition.

\section{PENDAHULUAN / INTRODUCTION}

Disrupsi ekonomi merupakan salah satu fenomena yang terjadi pada masa transformasi struktural dan memiliki keterkaitan erat dalam pergeseran tenaga kerja menuju arah industrialisasi (Das, et al., 2019). Lamb, et al. (2019) mengatakan bahwa menurunnya kualitas sektor tenaga kerja tertentu dipengaruhi adanya disrupsi yang mengakibatkan adanya pergeseran tenaga kerja pada sektor lain yang sedang berkembang. Sehingga, ketika disrupsi ekonomi terjadi secara meluas, penyerapan tenaga kerja pada sektor-sektor berbasis tradisional semakin terabaikan (Nurdany dan Kresnowati, 2019).

Dalam masa transformasi struktual, Indonesia juga mengalami disrupsi ekonomi yang sering halnya dikaitkan dengan munculnya transportasi online yang terjadi pada awal tahun 2015 hingga saat ini (Kasali, 2017). Disrupsi secara umum digambarkan sebagai inovasi yang berpotensi dalam menggantikan produk barang dan jasa yang dilakukan oleh perusahaanperusahaan besar. Akbarani (2018) menjelaskan adanya keterkaitan erat antara disrupsi dengan ketenagakerjaan terjadi pada fenomena disrupsi ekonomi.

Indonesia masih mengalami permasalahan terkait rendahnya minat pada sektor pertanian dalam masa transformasi struktural (Dartanto, et al., 2018). Transformasi struktural yang pada umumnya terjadi di negara berkembang sebagai indikasi pertumbuhan perekonomian (Azadi, et al., 2010 dan Carpio, 2015). Dari beberapa penelitian menunjukkan bahwa transformasi struktural ditunjukkan dari adanya perubahan Produk Domestik Bruto (PDB) dan pergeseran tenaga kerja yang berorientasi pada komoditas yang bernilai tinggi, seperti industri dan jasa, dibandingkan dengan komoditas yang bernilai rendah, yakni pertanian (Dartanto, et al., 2018, Daryanto, et al., 2013, Hartwig, 2013).

Perubahan yang terjadi pada kontribusi PDB menggambarkan bahwa sektor industri dan jasa telah mengungguli dan menjadikan sektor pertanian hingga pada titik terendah di sepanjang tahun 1960-2018 (Badan Pusat Statistik, 2018). Kontribusi pada sektor pertanian 
yang awalnya mendominasi dengan nilai 54 persen pada tahun 1960 mengalami kemerosotan di tahun 2018 dengan nilai 13 persen. Sedangkan kontribusi pada sektor industri dan jasa memiliki nilai terbesar melebihi 80 persen dimana masing-masing sektor industri dan jasa sebesar 41 persen dan 45 persen.

Gambar 1. Transisi Sektoral di Indonesia Tahun 1986-2018.

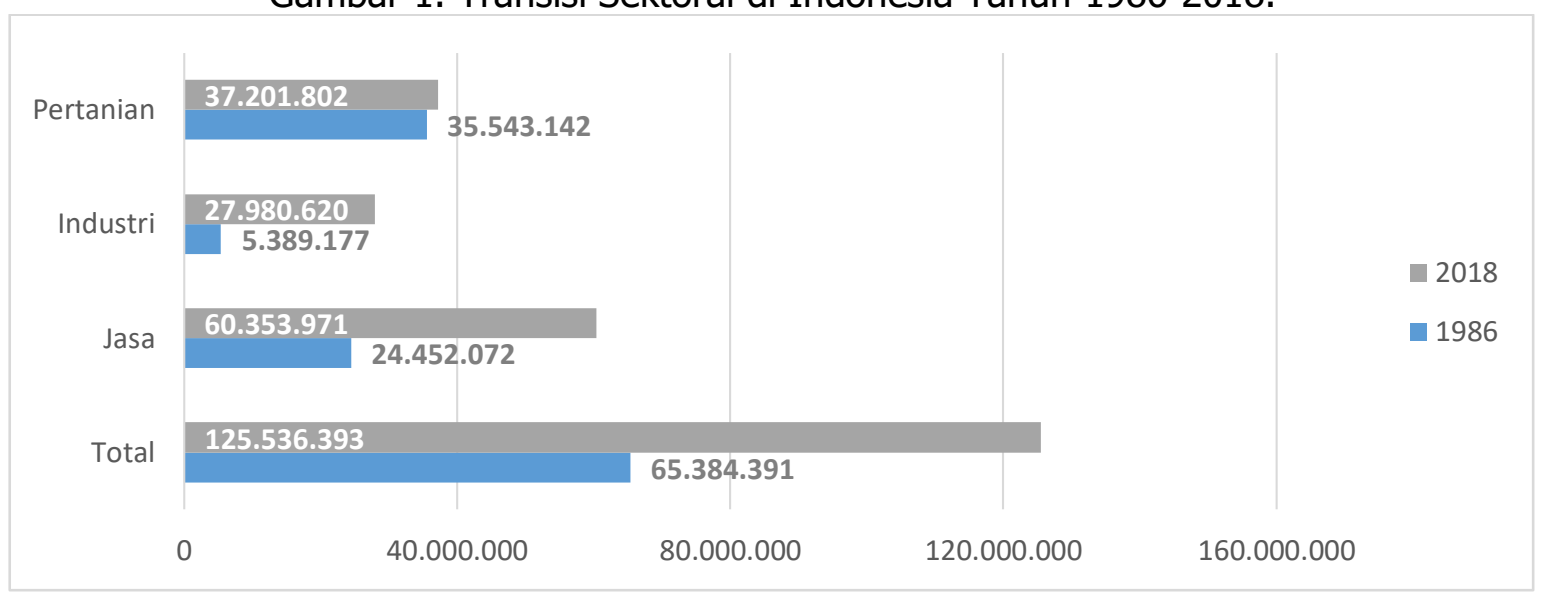

Sumber: Sakernas, dalam Badan Pusat Statistik (2019).

Dalam segi tenaga kerja, data Survei Angkatan Kerja Nasional 2019 menjelaskan bahwa peningkatan tenaga kerja setiap tahunnya juga hanya terserap pada sektor industri dan jasa (BPS, 2018). Hal ini diperjelas dengan selisih jumlah tenaga kerja sektor pertanian di tahun 1986 dan 2018 yang hanya meningkat sebesar 1.658.660 jiwa, sedangkan tenaga kerja pada sektor industri dan jasa memiliki peningkatan yang cukup besar dengan selisih 22.591.443 jiwa dan 35.901.899 jiwa.

Jika ditinjau dari kemajuan teknologi yang semakin massive dan besarnya perubahan pada tenaga kerja secara sektoral di sektor modern (non pertanian), sektor pertanian tidak dapat ditunjang lagi dengan penyerapan tenaga kerja (Suryahadi, et al., 2018). Untuk itu, peneliti berfokus pada pergeseran tenaga kerja yang terjadi dalam masa disrupsi ekonomi dengan melibatkan beberapa faktor lain yang mendukung terjadinya perubahan. Dalam penelitian ini, peneliti bertujuan melihat arah pergeseran penyerapan tenaga kerja secara sektoral dalam masa sebelum transisi (variabel independen) dan setelah transisi (variabel dependen). Dengan harapan, pemerintah dapat menyediakan lapangan pekerjaan sesuai dengan kebutuhan tenaga kerja Indonesia berdasarkan arah pergerakan transisi tenaga kerja sektoral. 
Intan, Pudjihardjo, Devanto. Transisi Penyerapan Tenaga Kerja Sektoral...

\section{TINJAUAN TEORITIK / LITERATURE REVIEW}

Teori transformasi struktural atau perubahan struktural menitikberatkan pada mekanisme transformasi ekonomi yang dialami oleh negara sedang berkembang yang awalnya bersifat tradisional dan berbasis pada sektor pertanian menuju ke struktur perekonomian yang lebih modern dan sangat didominasi oleh sektor industri dan jasa.

Gambar 2. Model Pertumbuhan Sektor Modern dalam Perekonomian Dua Sektor yang Mengalami Surplus Tenaga Kerja Hasil Rumusan Lewis

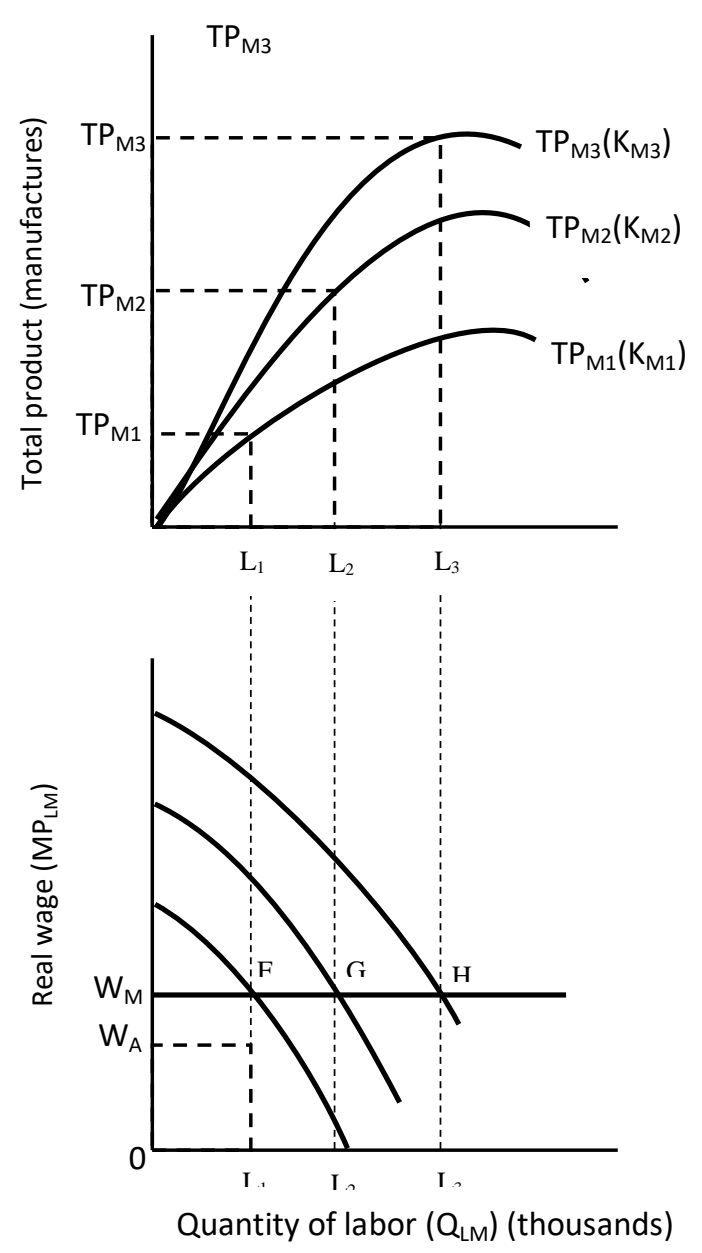

(a) Modern (industrial) sector
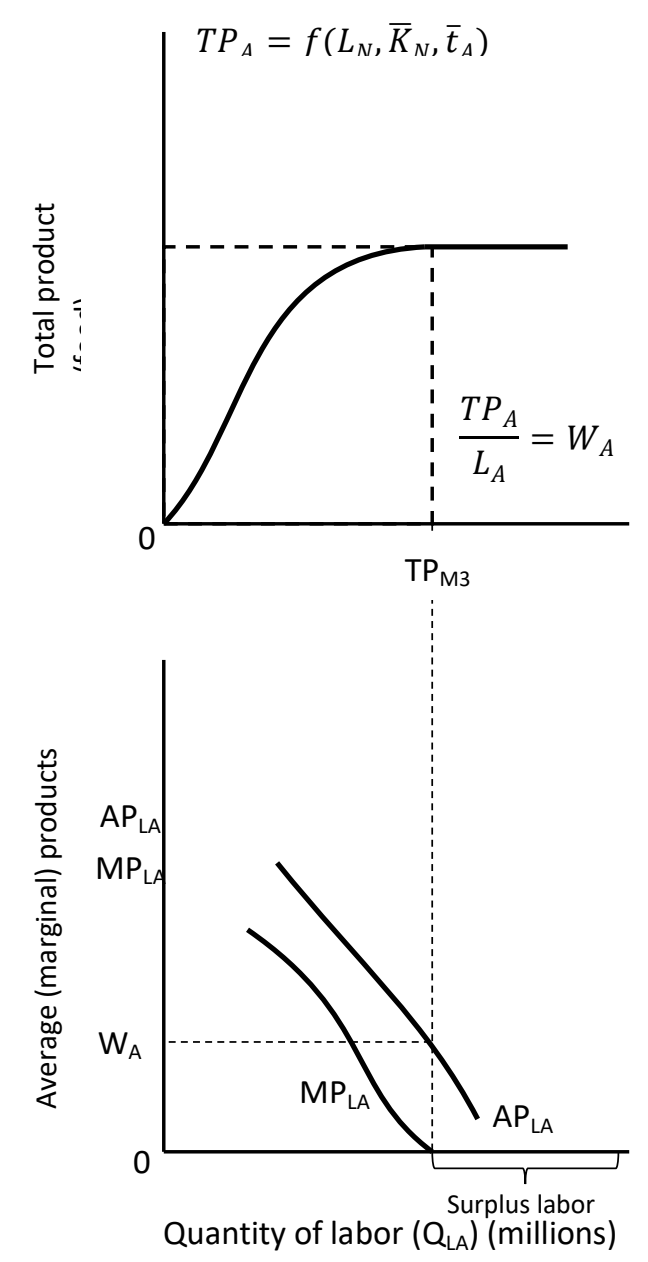

(b) Traditional (agricultural)

Sumber: Pembangunan Ekonomi, Todaro dan Smith (2006).

Teori yang dikemukakan oleh W. Arthur Lewis ini mengerucut pada dua sektor yang melihat bagaimana supply penawaran tenaga kerja terjadi antara dua sektor tersebut. Hal ini dilatarbelakangi dengan adanya peristiwa proses pembangunan di negara-negara Dunia Ketiga 


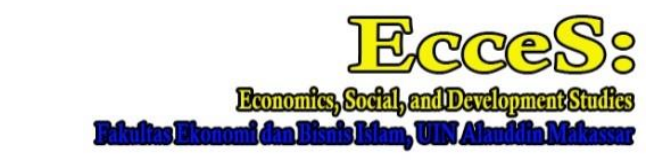

Volume 7 Nomor 1 Ed. Juni 2020: page 22-41 p-ISSN: 2407-6635 e-ISSN : 2580-5570

yang mengalami kelebihan penawaran tenaga kerja selama dekade 1960-an dan awal dekade 1970-an (Todaro dan Smith, 2006).

Dalam model ini, Lewis sering mendefinisikan sebagai surplus tenaga kerja (surplus labor) yang terjadi di sektor pertanian dan tenaga kerja bergeser pada sektor industri, jasa dan lainnya. Lewis menganggap adanya upah yang lebih tinggi pada sektor industri mengakibatkan tenaga kerja memilih sektor industri sebagai sektor yang dapat meningkatkan kesejahteraannya.

Perhatian utama model ini diarahkan pada terjadinya transfer tenaga kerja, peningkatan output dan peningkatan penyerapan tenaga kerja dari sektor tradisional menuju sektor modern. Pergeseran tenaga kerja dan pertumbuhan kesempatan kerja timbul karena adanya perluasan output pada sektor modern yang ditentukan oleh tingkat investasi di bidang industri dan akumulasi modal secara keseluruhan di sektor modern. Perluasan output juga didukung dengan tingginya upah di sektor modern dibandingkan dengan sektor tradisional. Yang mana pada sektor modern, outputnya lebih tinggi dibandingkan dengan sektor modern.

Dalam memutuskan masuk pada dunia tenaga kerja, individu atau seseorang yang telah bekerja memiliki beberapa faktor dalam memilih tenaga kerja sesuai dengan minat dan kondisi pasar tenaga kerja tersebut. Secara umum, perubahan tingkat upah dan waktu menentukan individu dalam memasuki pekerjaan mana yang harus individu pilih dengan kebutuhan yang sesuai (Becker, 1994). Jika individu menginginkan tingkat upah yang tinggi, maka waktu luang (leisure) yang digunakan semakin berkurang, dan sebaliknya. Sehingga akan terjadi substitusi antara bekerja dan keinginan individu dalam menggunakan waktu luangnya (Levey, 2015).

Efek subtsitusi antara tingkat upah dan alokasi waktu digambarkan pada kurva indeferens (Indifference Curve). Pada dasarnya, kurva indiferens menjelaskan tentang perilaku individu apabila dihadapkan pada barang dan jasa yang saling melengkapi kebutuhan individu. Namun pada konsep tenaga kerja, kurva menjelaskan kondisi tingkat upah dan waktu luang yang berperan satu sama lain. Dalam kurva indiferens, tingkat kepuasan individu merupakan penilaian utama bagaimana individu membentuk perilakunya.

Dalam menentukan tingkat kepuasan masing-masing individu, perubahan antara besaran tingkat upah dan alokasi waktu yang dibutuhkan menentukan perilaku individu dalam menghasilkan pendapatan dengan mempertimbangkan tingkat kepuasan yang didapat (Malik, 2018). Kenaikan tingkat upah di pasar kerja (asumsi pendapatan konstan) menyebabkan nilai 
Intan, Pudjihardjo, Devanto. Transisi Penyerapan Tenaga Kerja Sektoral...

per unit waktu dalam aktivitas kerja semakin meningkat dan individu cenderung untuk menambah pendapatan dan mengurangi waktu luangnya. Sebaliknya, jika tingkat upah menurun maka akan mendorong individu untuk menggunakan waktu kerjanya dengan waktu luang sebagai bentuk mempertahankan kepuasannya.

Gambar 3. Indefference Curve

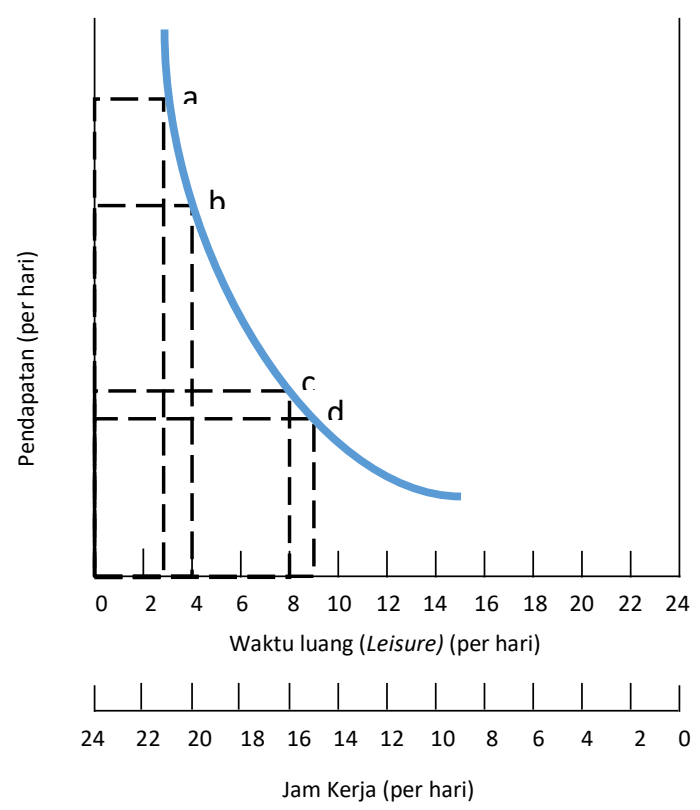

Sumber: Contemporary Labor Economics (2015).

Kurva indiferens menunjukkan berbagai kombinasi pendapatan dan waktu luang yang menghasilkan tingkat total kepuasan (utilitas) tertentu. Kurva miring ke bawah karena utilitas tambahan yang terkait dengan lebih banyak waktu luang harus diimbangi dengan pendapatan yang lebih sedikit sehingga total utilitas tetap tidak berubah. Cembungnya kurva mencerminkan semakin rendahnya tingkat substitusi waktu luang untuk pendapatan.

Dalam kurva indeferens menjelaskan kondisi yang berakar pada dua pertimbangan. Pertama, kemiringan kurva mencerminkan kesediaan subyektif individu untuk menggantikan antara waktu luang dan pendapatan. Dan kedua, kesediaan individu untuk mengganti waktu luang dengan pendapatan, atau sebaliknya, bervariasi dengan jumlah waktu luang dan pendapatan yang awalnya dimiliki (McConnell, dkk., 2015).

Pada masa disrupsi ekonomi yang semakin meluas, keputusan individu dalam memilih masuk pada pasar tenaga kerja tidak terbatas hanya pada tingkat upah dan alokasi waktu dalam satu lingkup tenaga kerja, namun keinginan individu dalam meningkatkan kepuasannya 


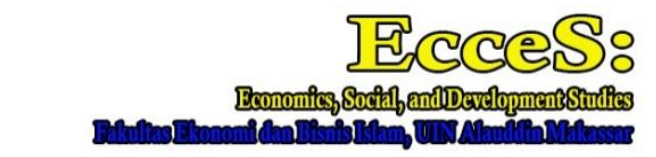

Volume 7 Nomor 1 Ed. Juni 2020: page 22-41

p-ISSN: 2407-6635 e-ISSN : 2580-5570

pada lingkup tenaga kerja lain juga dipertimbangkan. Disrupsi ekonomi memberikan pandangan bahwa tingkat upah dan alokasi waktu pada sektor lain mempengaruhi individu dalam memutuskan untuk berpindah pada lingkup tenaga kerja lain (sektor lain) (Lamb, et al. 2019). Kemajuan teknologi dan tingkat fleksibilitas waktu dalam bekerja menjadikan sektor modern menjadi keunggulan bagi tenaga kerja baru (new entrants) maupun yang memiliki pengalaman kerja untuk berpindah pada sektor tersebut.

Perpindahan tenaga kerja juga tidak hanya berdasarkan pada sektor, namun terlihat dari tenaga kerja formal dan informal. Nunez (2017), Mok dan Qian (2018) dan Guetierrez (2019) melakukan penelitian dengan memahami bagaimana tenaga kerja melakukan transisi dengan variabel tingginya tingkat pendidikan dan upah. Hal yang membedakan, penelitian Nunez (2017) bertujuan untuk melihat seberapa besar variabel tersebut berpengaruh terhadap perubahan transisi terhadap tenaga kerja formal maupun informal. Sedangkan Mok dan Qian (2018) lebih cenderung melihat tenaga kerja kategori usia muda dalam transisi tersebut. Hasil penelitian ini menunjukkan bagaimana tenaga kerja dengan tahun kelulusan yang tergolong baru dan usia muda lebih cenderung memilih pekerjaan pada sektor informal.

\section{METODE PENELITIAN / METHODS}

Regresi multinomial logit adalah model regresi yang digunakan untuk menyelesaikan kasus regresi dengan variabel dependen berupa data kualitatif berbentuk multinomial (lebih dari dua kategori) dengan satu atau lebih variabel independen (Harlan, 2018). Variabel dependen yang digunakan terbagi menjadi 3 kategori, yakni penyerapan tenaga kerja sektor pertanian, industri dan jasa. Dalam mendeteksi adanya perubahan penyerapan tenaga kerja antarsektor, peneliti menggunakan tenaga kerja sebelum transisi dengan sektor pertanian dan industri dan jasa terhadap penyerapan tenaga kerja yang setelah transisi. Dengan menggunakan data Survei Angkatan Kerja Nasional (Sakernas) Agustus 2018 yang meliputi 314.436 responden, variabel independen terbagi menjadi dua karakteristik, yakni karakteristik individual dan karakteristik sosial ekonomi.

Dari kategori variabel dependen $(Y)$ yang menjadi reference category adalah penyerapan tenaga kerja pada sektor jasa. Berikut adalah pemetaan kategori pada variabel $\mathrm{Y}$,

$$
Y=1 \text {, penyerapan tenaga kerja sektor pertanian, }
$$




$$
\begin{aligned}
& Y=2 \text {, penyerapan tenaga kerja sektor industri, } \\
& Y=3 \text {, penyerapan tenaga kerja sektor jasa, }
\end{aligned}
$$

Dengan transformasi logit maka terbentuk dua fungsi logit dalam persamaan 1 dan 2 sebagai berikut;

$$
\begin{aligned}
& P_{1}(x)=\ln \left[\frac{P(Y=1) 1 \mid x}{P(Y=1) 3 \mid x}\right] \ldots \\
& P_{2}(x)=\ln \left[\frac{P(Y=1) 2 \mid x}{P(Y=1) 3 \mid x}\right]
\end{aligned}
$$

Merujuk pada persamaan 2, maka model persamaan yang dapat diperoleh untuk penelitian ini yakni;

$$
\begin{aligned}
P(P T K i)=\beta_{0} & +\beta_{1} A g+\beta_{2} \text { Ind }+\beta_{3} \text { Sv }+\beta_{4} \text { Sex }+\beta_{5} \text { Gender }+\beta_{6} M a r+\beta_{7} U M K+\beta_{9} P S D \\
& +\beta_{10} P S M P+\beta_{11} P S M A K+\beta_{12} P D P T+\beta_{13} \text { Dom } \ldots \ldots \ldots \ldots \ldots \ldots \ldots \ldots \ldots \ldots \ldots \ldots \ldots \ldots
\end{aligned}
$$

Persamaan 3 menunjukkan PTK sebagai variabel dependen dengan membentuk dua model dengan kategori dasar sektor jasa.

Setelah dilakukan pengujian model multinomial logit, dilanjutkan dengan regresi marginal effect sebagai intepretasi koefisien dari masing-masing variabel independen terhadap tiga variabel dependen (Andini, 2019). Pada penelitian ini, marginal effect mengukur perubahan yang diskrit. Sehingga dapat melihat pengaruh secara parsial (Odd Ratio) dari masing-masing variabel independen (Gusniar, 2013).

\section{HASIL DAN PEMBAHASAN / RESULT AND DISCUSSION}

Badan Pusat Statistik Indonesia menunjukkan bahwa pergeseran tenaga kerja menuju sektor non pertanian sangat pesat (Badan Pusat Statistik, 2018). Pergeseran yang terjadi mengakibatkan tenaga kerja pada sektor pertanian menurun di titik terendah hingga 29,63 persen sepanjang tahun 1990 hingga 2018. Sebesar 25,48 persen, tenaga kerja sektor pertanian mengalami transisi menuju tenaga kerja sektor industri dan jasa sehingga mengakibatkan tenaga kerja pada sektor modern tersebut mendominasi dari keseluruhan total tenaga kerja di Indonesia sebesar 70,37 persen. Pencapaian kontribusi tersebut merupakan nilai yang terbesar sepanjang Indonesia mengalami proses menuju industrialisasi. 
Dugaan terjadinya transisi tenaga kerja pada sektor modern dibuktikan juga dengan hasil estimasi dari penelitian ini. Pada hasil odd ratio, secara transisi, sektor pertanian, industri dan jasa memiliki pengaruh signifikan terhadap penyerapan tenaga kerja pada setiap sektor pertanian, industri dan jasa. Pembeda antara setiap variabel transisi yakni adanya hubungan positif dan negatif dalam setiap perubahannya (Tabel 1). Hasil penelitian ini sejalan dengan penelitian dari Nunez (2017) dan Aldunate, et.al. (2019) yang menunjukkan adanya tingkat signifikansi dari transisi tenaga kerja antarsektor.

Gambar 3. Transisi Tenaga Kerja Sektoral di Indonesia Tahun 1990-2018.

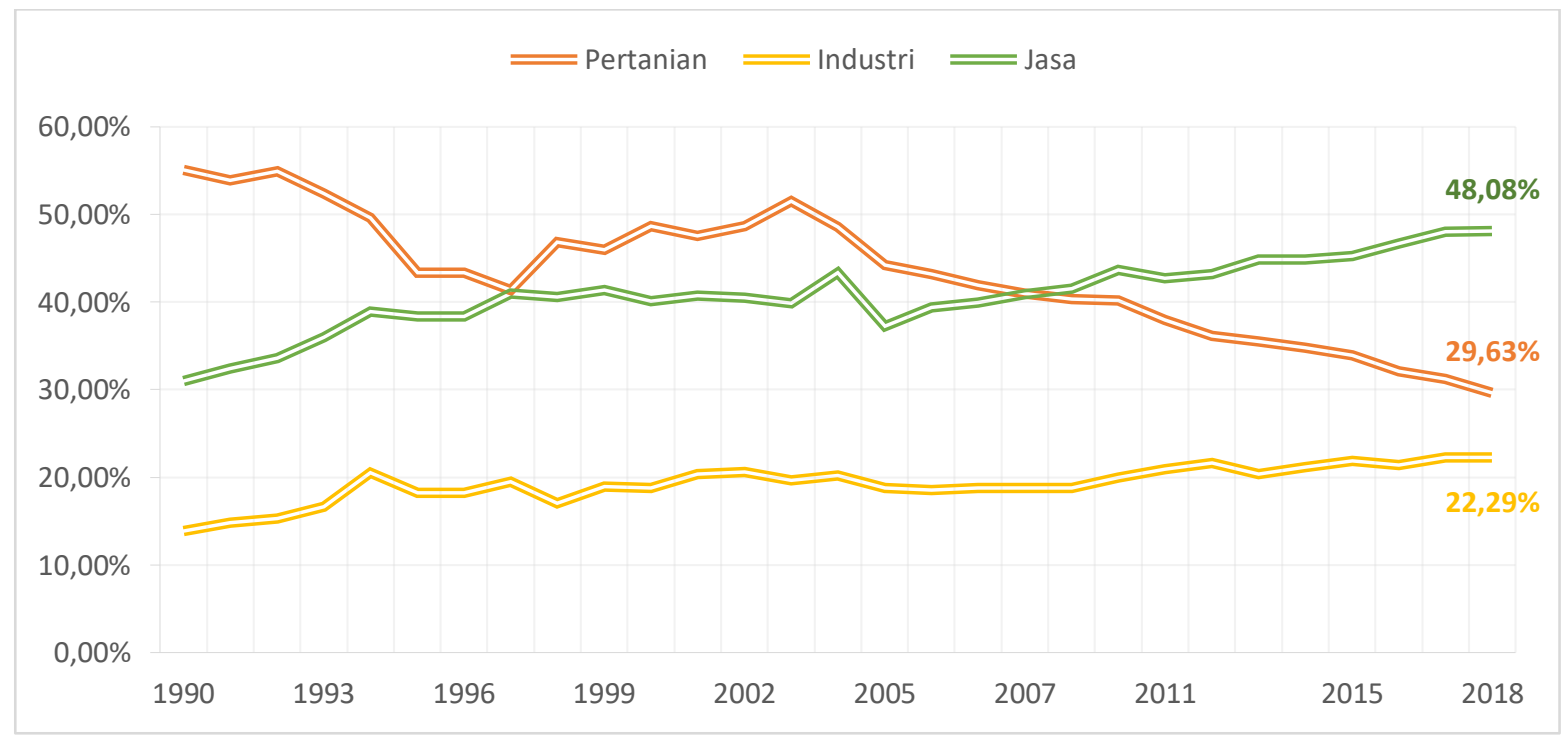

Sumber: Badan Pusat Statistik (2019).

Pada karakteristik individual dan sosial ekonomi, keseluruhan variabel independen juga berpengaruh signifikan yang artinya masing-masing variabel memiliki pengaruh terhadap penyerapan tenaga kerja tiap sektor. Namun pada variabel kawin, taraf nyata berada pada tingkat 5\% dan 10\%. Pengaruh signifikan yang diberikan sesuai dengan beberapa penelitian terhadap penyerapan tenaga kerja yakni Ngo (2018), Gutierrez, et al., (2019), Fiorini, et al., (2017), Parray (2017), Nilsson (2018), Mok and Qian (2018), dan Krishnamurty dan Kumar (2015). 


\section{Transisi Tenaga Kerja Sektor Pertanian menuju Tenaga Kerja Sektor Pertanian,} Industri dan Jasa

Variabel transisi tenaga kerja sektor pertanian menunjukkan peluang lebih besar terserapnya tenaga kerja hanya terjadi pada sektor industri dengan nilai positif sebesar 17,94 persen dibandingkan pada sektor pertanian dan jasa dengan nilai negatif sebesar 10,06 persen dan 7,87 persen.

Tabel 1. Hasil EstimasiAnalasis Multinomial Logit (Marginal Effect).

\begin{tabular}{|c|c|c|c|c|c|c|}
\hline \multirow[t]{3}{*}{ Variabel } & \multirow{2}{*}{\multicolumn{2}{|c|}{$\begin{array}{c}\text { Penyerapan } \\
\text { Tenaga Kerja } \\
\text { Sektor Pertanian } \\
P T K=1\end{array}$}} & \multirow{2}{*}{\multicolumn{2}{|c|}{$\begin{array}{c}\text { Penyerapan } \\
\text { Tenaga Kerja } \\
\text { Sektor Industri } \\
P T K=2\end{array}$}} & \multirow{2}{*}{\multicolumn{2}{|c|}{$\begin{array}{c}\text { Penyerapan } \\
\text { Tenaga Kerja } \\
\text { Sektor Jasa } \\
P T K=3\end{array}$}} \\
\hline & & & & & & \\
\hline & M.E. & Prob. & M.E. & Prob. & M.E. & Prob. \\
\hline \multicolumn{7}{|c|}{ Transisi Sektoral } \\
\hline \multirow{2}{*}{$A g$} & $-0,1006$ & $0,000 * * *$ & 0,1794 & $0,000 * * *$ & $-0,0787$ & $0,000 * * *$ \\
\hline & \multicolumn{2}{|c|}{ (-) Sig. } & \multicolumn{2}{|c|}{ (+) Sig. } & \multicolumn{2}{|c|}{ (-) Sig. } \\
\hline \multirow{2}{*}{ Ind } & $-0,0928$ & $0,000 * * *$ & 0,1650 & $0,000 * * *$ & $-0,0722$ & $0,000 * * *$ \\
\hline & \multicolumn{2}{|c|}{ (-) Sig. } & \multicolumn{2}{|c|}{ (+) Sig. } & \multicolumn{2}{|c|}{ (-) Sig. } \\
\hline \multirow{2}{*}{$S v$} & $-0,1554$ & $0,000 * * *$ & 0,0157 & $0,012 * *$ & 0,1396 & $0,000 * * *$ \\
\hline & \multicolumn{2}{|c|}{ (-) Sig. } & \multicolumn{2}{|c|}{ (+) Sig. } & \multicolumn{2}{|c|}{ (+) Sig. } \\
\hline \multicolumn{7}{|c|}{ Karakteristik Individual } \\
\hline \multirow{2}{*}{ Sex } & $-0,1168$ & $0,000 * * *$ & 0,0706 & $0,000 * * *$ & 0,0462 & $0,000 * * *$ \\
\hline & \multicolumn{2}{|c|}{ (-) Sig. } & \multicolumn{2}{|c|}{ (+) Sig. } & \multicolumn{2}{|c|}{ (+) Sig. } \\
\hline \multirow{2}{*}{ Gender } & 0,7666 & $0,000 * * *$ & 0,0979 & $0,000 * * *$ & $-0,1746$ & $0,000 * * *$ \\
\hline & \multicolumn{2}{|c|}{ (+) Sig. } & \multicolumn{2}{|c|}{ (+) Sig. } & \multicolumn{2}{|c|}{ (-) Sig. } \\
\hline \multirow{2}{*}{ Mar } & 0,0108 & $0,000 * * *$ & $-0,0040$ & $0,061 *$ & $-0,0067$ & $0,000 * * *$ \\
\hline & \multicolumn{2}{|c|}{ (+) Sig. } & \multicolumn{2}{|c|}{ (-) Sig. } & \multicolumn{2}{|c|}{ (-) Sig. } \\
\hline \multicolumn{7}{|c|}{ Karakteristik Sosial Ekonomi } \\
\hline$J U M K$ & 0,0255 & $0,000 * * *$ & $-0,0681$ & $0,000 * * *$ & 0,0425 & $0,000 * * *$ \\
\hline IUMN & & Sig. & & Sig. & & Sig. \\
\hline$P S D$ & $-0,1063$ & $0,000 * * *$ & 0,0214 & $0,000 * * *$ & 0,0849 & $0,000 * * *$ \\
\hline PSD & & & & Sig. & & Sig. \\
\hline DCMD & $-0,1902$ & $0,000 * * *$ & 0,0139 & $0,000 * * *$ & 0,1763 & $0,000 * * *$ \\
\hline PSMP & & & & Sig. & & Sig. \\
\hline DSM M & $-0,3037$ & $0,000 * * *$ & $-0,0235$ & $0,000 * * *$ & 0,3272 & $0,000 * * *$ \\
\hline РSМАК & & & & Sig. & & Sig. \\
\hline PDPT & $-0,3676$ & $0,000 * * *$ & $-0,1631$ & $0,000 * * *$ & 0,5307 & $0,000 * * *$ \\
\hline PDPI & & & & Sig. & $(+$ & Sig. \\
\hline 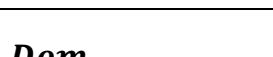 & $-0,3735$ & $0,000 * * *$ & 0,0649 & $0,000 * * *$ & 0,3086 & $0,000 * * *$ \\
\hline Dom & & & $(+$ & Sig. & $(+$ & Sig. \\
\hline
\end{tabular}

Sumber: Hasil olah STATA 13.2 (2020). ***1\%, **5\%, *10\%. 


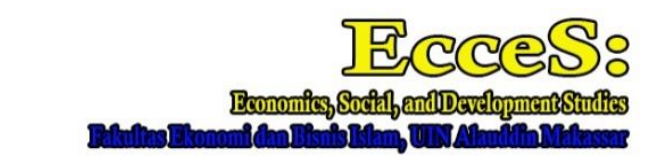

Volume 7 Nomor 1 Ed. Juni 2020: page 22-41 p-ISSN: 2407-6635 e-ISSN : 2580-5570

Dari nilai tersebut menjelaskan bahwa tenaga kerja yang awalnya bekerja pada sektor pertanian berpeluang lebih besar terserapnya pada sektor industri dibandingkan dengan sektor pertanian dan jasa. Hal ini sesuai dengan hasil penelitian dari Dwipradnyana (2014) dan Pramudiana (2017) yang menyatakan bahwa banyaknya buruh tani yang mencari pekerjaan pada sektor industri.

Fenomena konversi lahan pertanian memperkuat dugaan bahwa tenaga kerja sektor pertanian yang kehilangan pekerjaannya beralih pada sektor industri dengan skill yang memadai tanpa membutuhkan upgrading skill (Dwipradnyana, 2014). Pramudiana (2017) menyatakan dalam hasil penelitiannya di Jawa Timur bahwa akibat dari berkurangnya lahan pertanian yang meluas menyebabkan buruh tani harus mencari pekerjaan lain. Sebagian diantaranya beralih ke pabrik karena susahnya mencari pekerjaan kembali pada sektor pertanian dan sisanya bekerja dengan membuka toko kecil sebagai tambahan pendapatan. Sehingga buruh petani mencoba beralih ke pekerjaan lain sesuai dengan skill yang dimiliki yang umumnya terserap pada sektor industri (Suryahadi, et al., 2018).

Berbeda pada sektor jasa, peluang terserapnya buruh tani pada sektor ini masih sulit untuk dijangkau pada masa disrupsi ekonomi sekarang ini. Munculnya sektor jasa khususnya lapangan pekerjaan berbasis online (ojek, online shop) tidak dapat dijangkau dikarenakan keterbatasan skill ataupun kebutuhan yang dimiliki buruh tani. Herdianti et al., (2014) menjelaskan bahwa adanya kemungkinan tenaga kerja pertanian berpindah menuju sektor jasa yakni adanya peningkatan penyerapan pada hotel dan restoran. Namun peningkatan penyerapan pada sektor hotel dan restoran sebagian hanya menyerap tenaga kerja usia muda, dimana hal ini tidak berlaku bagi tenaga kerja usia menengah (40-64 tahun) sehingga peluang terserapnya lebih kecil.

Sedangkan terserapnya tenaga kerja pertanian kembali pada sektor pertanian juga memiliki peluang lebih kecil disebabkan massivenya alih fungsi lahan pertanian menuju non pertanian (Kusdiane, et al., 2018). Bertambahnya perluasan lahan pertanian 100 hektar setiap tahunnya mengakibatkan semakin berkurangnya lahan garapan dan mendorong transisi tenaga kerja menuju sektor lainnya. Dengan adanya data dari BPS 2018 bahwa penurunan penyerapan tenaga kerja sektor pertanian yang diawali pada tahun 2003 hingga saat ini (Gambar 1), memperkuat hasil penelitian ini bahwa peluang terserapnya kembali tenaga kerja pada sektor pertanian semakin kecil. 
Intan, Pudjihardjo, Devanto. Transisi Penyerapan Tenaga Kerja Sektoral...

Secara umum, tenaga kerja memilih untuk melakukan transisi atau tidak didasari dengan adanya masing-masing tingkat kepuasan yang dapat diperoleh dari setiap sektor (Malik, 2018). Antara alokasi waktu yang dikeluarkan dan pendapatan yang didapatkan merupakan dua hal yang dipertimbangkan dalam pemenuhan kebutuhan setiap sektor. Diketahui bahwa sektor pertanian memiliki tingkat pendapatan yang rendah dengan alokasi waktu yang tidak dapat diprediksi jika dikaitkan dengan mengolah lahan pertanian (Pramudiana, 2017). Berbeda dalam pengalokasian waktu yang jelas pada sektor formal khususnya pada sektor non pertanian yang memiliki jam kerja yang terhitung jelas dan pendapatan yang setara dengan alokasi waktu yang dikorbankan. Sehingga, hal tersebut menjadi salah satu dasar mengapa tenaga kerja sektor pertanian beralih pada sektor lain, khususnya pada sektor industri.

\section{Transisi Tenaga Kerja Sektor Industri menuju Tenaga Kerja Sektor Pertanian, Industri dan Jasa}

Transisi tenaga kerja dari sektor industri menuju sektor pertanian, industri maupun jasa menunjukkan hasil yang signifikan dimana mengartikan bahwa pekerja yang awalnya bekerja pada sektor industri melakukan transisi pada keseluruhan sektor. Namun hasil dari estimasi marginal effect menunjukkan bahwa setiap penyerapannya tidak selalu berpeluang tinggi pada setiap sektor. Dengan nilai positif sebesar 13,33 persen, penyerapan tenaga kerja sektor industri menjelaskan bahwa peluang terserapnya tenaga kerja yang awalnya bekerja di sektor industri hanya terjadi pada sektor industri itu sendiri. Berbeda dengan penyerapan tenaga kerja pada sektor pertanian dan jasa yang memiliki nilai negatif yakni sebesar 4,15 persen dan 9,18 persen yang berarti peluang terserapnya lebih kecil terhadap dua sektor tersebut.

Sesuai dengan hasil penelitian, tenaga kerja yang awalnya bekerja pada sektor industri tidak melakukan transisi menuju sektor lain melainkan kembali terserap pada sektor industri. Di Indonesia, meskipun penyerapan tenaga kerja sektor industri berada pada posisi terendah dari keseluruhan sektor, namun terjadi peningkatan yang signifikan di setiap tahunnya (Gambar 3). Kementerian Perindustrian mencatat bahwa selama empat tahun terakhir sektor industri mengalami peningkatan sebesar 2,7 juta jiwa. Hal ini mengindikasikan bahwa kecilnya peluang terjadinya transisi tenaga kerja sektor industri menuju sektor lain.

Menurunnya penyerapan tenaga kerja pada sektor pertanian mengindikasikan bahwa kecilnya kemungkinan adanya transisi maupun tenaga kerja baru yang masuk (BPS, 2018). Tabel 1 tentang perubahan penyerapan tenaga kerja sektoral di tahun 1986 dan 2017 menjelaskan adanya gap yang cukup tinggi dalam perubahan kontribusi tenaga kerja pertanian 


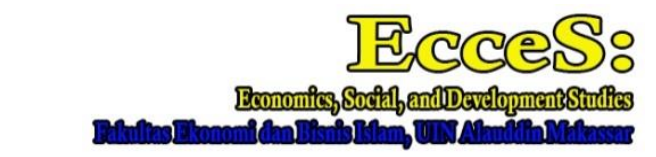

Volume 7 Nomor 1 Ed. Juni 2020: page 22-41 p-ISSN: 2407-6635 e-ISSN : 2580-5570

pada keseluruhan angkatan kerja yang bekerja di Indonesia. Hal ini menguatkan argumen dari hasil penelitian bahwa peluang terserapnya tenaga kerja sektor industri pada tenaga kerja sektor pertanian tidak dimungkinkan.

Peluang terserapnya tenaga kerja kembali pada sektor yang sama, dimana tenaga kerja industri memilih tidak beralih dari sektor industri, didukung oleh penelitian dari Guiterrez, et al. 2019 dan Aldunate, et al. (2019). Gutierrez, et al. (2019) menyatakan dalam hasil penelitiannya bahwa transisi yang dilakukan tidak akan berbeda jauh dari pekerjaan pertama dan hal tersebut yang menyebabkan kembalinya tenaga kerja terserap pada sektor yang sama. Aldunate, et al. (2019) juga mengatakan bahwa pentingnya jenjang karir yang lebih stabil, khususnya pada tenaga kerja formal, mengakibatkan tenaga kerja pada sektor industri memilih untuk tidak berpindah pada sektor lain.

\section{Transisi Tenaga Kerja Sektor Jasa menuju Tenaga Kerja Sektor Pertanian, Industri dan Jasa}

Variabel transisi sektor jasa menjelaskan adanya transisi tenaga kerja menuju keseluruhan sektor dengan masing-masing nilai sebesar 15,54 persen pada sektor pertanian, 1,57 persen pada sektor industri, dan 13,96 persen pada sektor jasa. Jika meninjau dari hasil signifikansi pengujian estimasi, variabel transisi sektor jasa memiliki peluang terserapnya pada penyerapan keseluruhan sektor. Namun arah signifikansi menjelaskan bahwa tenaga kerja sektor jasa berpeluang lebih besar terserapnya hanya pada sektor industri dan jasa.

Fenomena transformasi struktural yang didasari oleh Teori Chenery mendukung kuat hasil estimasi dari penelitian ini yang menggambarkan kondisi pergeseran tenaga kerja menuju sektor non pertanian (Tambunan, 2001). Meningkatnya PDB pada sektor non pertanian dan diikuti dengan perpindahan menuju sektor manufaktur dan jasa merupakan bukti adanya transformasi struktural yang terjadi di Indonesia.

Adanya perkembangan inovasi dan teknologi saat ini menjadikan tenaga kerja sektor jasa memilih untuk berpindah pada sektor berbasis teknologi dan menurunnya minat tenaga kerja pada sektor tradisional (Gutierrez, et al., 2019). Menurunnya minat pada sektor pertanian telah dijelaskan dalam penelitian Rachman (2019) yang menjelaskan bahwa sangat kecil kemungkinan terjadinya perpindahan menuju sektor pertanian tanpa adanya perubahan pada sektor pertanian sendiri. 
Intan, Pudjihardjo, Devanto. Transisi Penyerapan Tenaga Kerja Sektoral...

Sesuai dengan hasil estimasi, berpindahnya tenaga kerja sektor jasa menuju sektor industri juga memiliki peluang lebih besar namun dengan kemungkinan yang kecil. Gutierrez, et al. (2019) juga menjelaskan dalam penelitiannya bahwa transisi antarsektor memungkinkan dilakukan jika skill yang dibutuhkan tidak jauh berbeda dengan sektor awal. Sehingga, kemungkinan tenaga kerja sektor jasa menuju sektor industri lebih kecil dibandingkan dengan sektor jasa sendiri. Hal ini juga diperkuat signifikannya peningkatan tenaga kerja sektor jasa dari tahun ke tahun sehingga kemungkinan perpindahan menuju sektor lain sangat kecil.

\section{Pola Transisi Tenaga Kerja di Indonesia}

Estimasi penelitian ini terdiri dari variabel utama dan variabel control sebagai variabel independen yang berpengaruh pada variabel dependen, yakni penyerapan tenaga kerja sektoral di Indonesia. Namun, hipotesis dalam penelitian ini hanya berfokus pada variabel utama yakni tenaga kerja sektoral tanpa melibatkan variabel control yang terdiri dari karakteristik individual dan sosial ekonomi. Sehingga, peneliti akan membahas pergerakan arah transisi tenaga kerja sektoral yang terjadi di Indonesia.

Berikut merupakan pola pergerakan transisi tenaga kerja sektoral yang terdiri dari sektor pertanian, industri dan jasa yang terjadi di Indonesia dengan menggunakan data Sakernas Agustus 2018.

\section{Gambar 4. Pola Transisi Tenaga Kerja Sektoral di Indonesia}

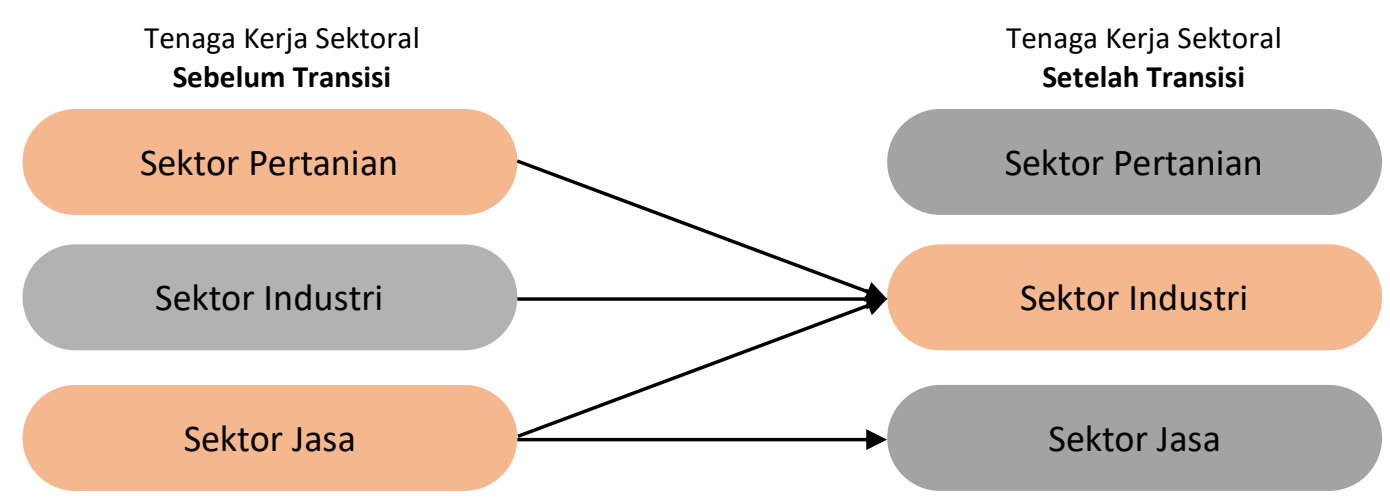

Sumber: Diolah Peneliti (2020).

Dari hasil penelitian ini dapat disimpulkan bahwa sektor yang menjadi tujuan dalam transisi tenaga kerja hanya sektor non pertanian (industri dan jasa) (Gambar 4). Sektor industri merupakan sektor yang menjadi tujuan utama transisi tenaga kerja di tahun 2018 dibandingkan 


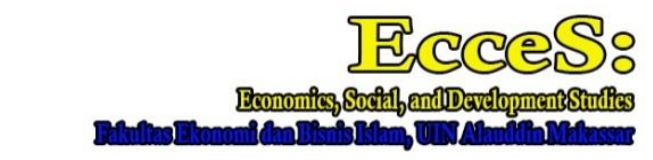

Volume 7 Nomor 1 Ed. Juni 2020: page 22-41 p-ISSN: 2407-6635 e-ISSN : 2580-5570

dengan sektor lainnya. Sedangkan sektor jasa tidak menyerap adanya transisi dari tenaga kerja lain melainkan hanya pada sektor jasa itu sendiri.

Dengan melihat pergerakan tren dari penyerapan tenaga kerja sektor pertanian yang terus menunjukkan grafik menurun di sepanjang tahun transformasi struktural, tidak mengherankan apabila sektor lain maupun sektor pertanian sendiri tidak memilih untuk berpindah pada sektor tersebut. Tingginya bonus demografi yang dialami Indonesia menjadi salah satu alasan menurunnya minat tenaga kerja usia muda berpindah pada sektor pertanian (Rachman, 2019). Tenaga kerja muda mendefinisikan sektor pertanian sebagai sektor yang tidak berperan pada era sekarang dalam pemenuhan kebutuhan (upah yang dihasilkan). Stigma yang terus tumbuh pada kondisi berkembangnya sektor lain dapat dikatakan lebih modern menurunkan jumlah tenaga kerja muda pada sektor pertanian (Nurhady dan Kresnowati, 2017).

Pada kenyataannya, meskipun tenaga kerja pada sektor pertanian menunjukkan penurunan, di tahun 2018, Kementerian Pertanian menyebutkan bahwa adanya peningkatan produksi dari tanaman pangan sawah non irigasi, khususnya produksi jagung dan kedelai (Kementan, 2019). Namun, meskipun kondisi produksi meningkat setiap tahunnya, jika tenaga kerja masih memandang sektor pertanian adalah sektor yang tidak competitive dalam menghasilkan nilai tambah yang tinggi, produktivitas pertanian juga akan menurun secara berkala. Beberapa alasan lain yang menjadi faktor rendahnya tenaga kerja sektor pertanian maupun sektor lain berpindah pada sektor pertanian yakni massive-nya alih fungsi lahan pertanian yang berganti menjadi lahan non pertanian dan tingkat kesejahteraan yang dihasilkan tidak memiliki nilai tambah yang sepadan (Pramudiana, 2017).

Dari pola transisi tenaga kerja sektoral terlihat bahwa sektor yang paling menyerap banyak tenaga kerja dari sektor lainnya yakni sektor industri. Hasil penelitian ini sesuai dengan grafik dari penyerapan tenaga kerja yang terjadi pada sektor industri pada sepanjang tahun terjadinya transformasi struktural. Dalam perkembangannya, meskipun tenaga kerja sektor industri berada pada urutan terakhir dibandingkan dengan kedua sektor lain, namun pergerakan yang dimiliki grafik tersebut tidak memiliki penurunan penyerapan (Gambar 3).

Pendidikan SD dan SMP yang merupakan mayoritas tingkat pendidikan yang dimiliki oleh sebagian tenaga kerja di Indonesia juga terserap pada sektor industri khususnya pada industri pengolahan atau manufaktur (Gusman, 2019). Hal ini sesuai dengan kemajuan pada kinerja industri manufaktur yang menjadi kontributor terbesar bagi PDB nasional yang tercatat di angka 
Intan, Pudjihardjo, Devanto. Transisi Penyerapan Tenaga Kerja Sektoral...

19,83 persen (Kemenperin, 2018). Perpindahan tenaga kerja pada sektor industri manufaktur memang terbilang hal yang mudah dilakukan oleh tenaga kerja usia muda berpendidikan rendah (lulusan SD dan SMP) dikarenakan skill yang dibutuhkan adaptatif dan peralatan yang digunakan sudah tersedia oleh perusahaan manufaktur itu sendiri. Sehingga, terserapnya tenaga kerja sektor lain pada sektor industri sesuai dengan kondisi masa kembang tumbuhnya industri manufaktur di tahun 2018.

Secara umum, jika tenaga kerja pada sektor tertentu meningkat, maka bertambahnya jumlah tenaga kerja tersebut dapat berasal dari berpindahnya tenaga kerja sektor lain menuju sektor tersebut, namun berbeda dengan sektor jasa. Hal yang menarik dari hasil penelitian ini adalah transisi tenaga kerja menuju sektor jasa hanya terserap dari sektor jasa itu sendiri, namun dengan kondisi pertumbuhan tenaga kerja di sektor ini memiliki jumlah terbesar dibandingkan penyerapan tenaga kerja pada sektor lainnya. Dapat diartikan bahwa berpindahnya tenaga kerja sektor lain pada sektor jasa bukan merupakan hal mudah khususnya pada era disrupsi ekonomi yang telah menguasai sektor jasa.

Pada latar belakang telah dijelaskan besarnya pengaruh disrupsi ekonomi pada sektor modern yang berakibat penggantian lapangan kerja yang berbasis teknologi, khususnya pada sektor jasa transportasi seperti halnya ojek online. Pada umumnya, masyarakat mengetahui secara garis besar bahwa mayoritas tenaga kerja ataupun pengangguran memilih bekerja menjadi ojek online karena dirasa pendaftaran untuk pekerjaan ini mudah, namun ternyata berbeda seperti kenyataannya. Salah satu sopir ojek online mengatakan bahwa banyaknya persyaratan yang harus dilengkapi dan banyaknya persaingan dalam penerimaan sebagai driver di salah satu perusahaan tersebut. Karena sulitnya mendapatkan account driver, ada beberapa driver lainnya yang menyewakan akun pada perusahaan lainnya agar memudahkan inidividu lain dengan berprofesi sebagai driver ojek online.

Berbeda pada sektor jasa keuangan dan sektor jasa pada profesi, penyerapan tenaga kerja yang terjadi umumnya tidak berasal dari tenaga kerja sektor lain, melainkan pekerja yang masih fresh graduate (new entrants) yang mana tenaga kerja yang masih baru tidak digunakan dalam penelitian ini. Sehingga dapat dikatakan bahwa peluang perpindahan tenaga kerja dari sektor lain menuju sektor jasa memiliki kemungkinan yang kecil. Dan diduga new entrants merupakan tenaga kerja yang memiliki pengaruh besar dalam terserapnya pada sektor jasa, bukan transisi tenaga kerja dari sektor lain. 


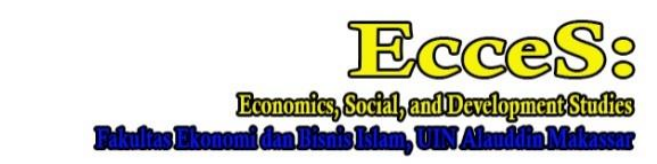

Volume 7 Nomor 1 Ed. Juni 2020: page 22-41

p-ISSN: 2407-6635 e-ISSN : 2580-5570

\section{KESIMPULAN / CONCLUSION}

Era disrupsi ekonomi menunjukkan adanya perubahan tenaga kerja yang cenderung berpindah pada sektor industrialisasi (sektor industri dan jasa). Dengan mempertimbangkan leisure dengan tingkat upah yang diterima, pekerja pada sektor pertanian memilih untuk berpindah pada sektor lain yang lebih menjanjikan. Tidak hanya transisi menuju sektor lain, studi ini juga menunjukkan bahwa besarnya kemungkinan pekerja memilih untuk tetap berada di sektor yang sama sesuai dengan perspektif mereka sendiri. Penyerapan pada sektor industri memiliki serapan yang paling diminati dibandingkan dengan sektor jasa yang membutuhkan upgrading skillyang belum sepenuhnya adaptatif.

Selain transisi sektoral, beberapa karakteristik individu dan ekonomi sosial memiliki pengaruh signifikan terhadap penyerapan tenaga kerja. Mengenai usia, penelitian ini menemukan bahwa tenaga kerja muda memiliki lebih sedikit penyerapan dalam pertanian dan dibutuhkan di sektor lain. Kemudian, pekerja perempuan memiliki nilai terbesar untuk penyerapan di sektor jasa daripada yang lain yang menyebabkan kesenjangan gender. Pendidikan juga menunjukkan bahwa tingginya tingkat pendidikan yang dicapai tidak berpengaruh pada penyerapan pertanian tetapi berdampak pada sektor jasa.

\section{DAFTAR PUSTAKA / REFERENCES}

Akbarani, I. 2018. Tantangan Era Ekonomi Disruptif. [Online]. Available at: https://kumparan.com/izza-akbarani/tantangan-era-ekonomi-disruptif (Diakses pada tanggal 12 Januari 2020)

Aldunate, Contreras, dan Tapia. 2019. Sectoral Transitions Between Formal Wage Jobs in Chile. Working Paper No. 836. Santiago: Central Bank of Chile.

Andini, A Z. 2019. Pengaruh Karakteristik Demografi dan Sosial-Ekonomi Terhadap Probabilitas Bekerja di Sektor Pariwisata, Non-Pariwisata dan Tidak Bekerja di Provinsi Bali. Thesis. Universitas Brawijaya: Indonesia.

Azadi, Ho, and Hasfiati. 2010. Agricultural Land Conversion Drives: A Comparison between Less Developed, Developing, and Developed Countries. Land Degradation \& Development. Netherlands: Wiley Online Library.

Becker, G. S. 1994. Human Capital: A Theoretical and Empirical Analysis, with Special Reference to Education. [online]. Available at: https://www.nber.org/books/beck94-1 (Diakses pada tanggal 12 Desember 2019). 
Intan, Pudjihardjo, Devanto. Transisi Penyerapan Tenaga Kerja Sektoral...

Badan Pusat Statistik. 2018. Penduduk Berumur 15 Tahun Ke Atas yang Bekerja Selama Seminggu yang Lalu Menurut Lapangan Pekerjaan Utama. Badan Pusat Statistik: Indonesia.

Carpio, X D., Nguyen H., Pabon L., Wang L C. 2015. Do minimum wages affect employment? Evidence from The Manufacturing Sector in Indonesia. Journal of Labor and Development, 4(17).

Dartanto, T, Yuan E Z W, Sofiyandi, Y. 2017. Structural Transformation and the Dynamics of Income Equality in Indonesia: 1996-2014. Kuznets Beyond Kuznets: Chapter 10. Tokyo: Asian Development Bank Institute.

Daryanto, A, Lumaksono A, Achsani N A, Asmara S, Yuwono M, Asnawi Y H, Suhendi. 2015. Transformasi Struktural Usahatani dan Petani Indonesia. Jakarta: Badan Pusat Statistik.

Das, et al. 2016. Unlocking Indonesia's Digital Opportunity. McKinsey \& Company: McKinsey Indonesia Office.

Das, et al. 2019. Automation and The Future of Work in Indonesia: Jobs Lost, Jobs Gained, Jobs Changed. McKinsey \& Company: McKinsey Indonesia Office.

Dwipradnyana, I M M. 2014. Faktor-Faktor yang Mempengaruhi Konversi Lahan Pertanian serta Dampaknya Terhadap Petani: Studi Kasus Subak Jadi, Kecamatan Kediri, Tabanan. Thesis. Universitas Udayana: Denpasar.

Fiorini, M., Hoekman, B., Malgouyres, C. 2017. Services Policy Reform and Manufacturing Employment: Evidence from Transition Economies. CEP Working Paper 2017/7.

Guetierrez, I A, Kumar, K B, Mahmud, M, Munshi, F, Nataraj, S. 2019. Transitions between Informal and Formal Employment: Results from A Worker Survey in Bangladesh. Journal of Development and Migration, 9 (3) p. 124-135.

Gusman, Hanif. 2019. 43\% Tenaga Kerja Lulusan SD \& SMP, Apa Indonesia Siap Industri 4.0? Tirto id. https://tirto.id/43-tenaga-kerja-lulusan-sd-smp-apa-indonesia-siap-industri-40-djZj

Hartwig, Jochen. 2013. Structural Change, Aggregate Demand and Employment Dynamics in the OECD, 1970-2010. Journal of Structural Change and Economic Dynamics, 34, p. 36-45.

Herdianti, dkk. 2015. Analisis Transformasi Struktur Ekonomi dan Perubahan Proporsi Tenaga Kerja Provinsi Jawa Timur 1998-2012. International Journal of Social and Local Economic Governance Vol. 1 No. 1 April 2015 hal. 68-74.

Kasali, R. 2017. Meluruskan Pemahaman Soal "Disruption". [online]. https://money.kompas.com/read/2017/05/05/073000626/meluruskan.pemahaman.soal.dis ruption.?page=all [Diakses pada tanggal 12 Januari 2020]

Kemenperin. 2018. Kinerja Industri Manufaktur Masih Positif di Triwulan II-2018. Kementerian Perindustrian Republik Indonesia. https://kemenperin.go.id/artikel/19543/Kinerja-IndustriManufaktur-Masih-Positif-di-Triwulan-II-2018 
Kementan. 2019. Laporan Kinerja Kementerian Pertanian Tahun Anggaran 2018. Kementerian Pertanian Republik Indonesia. file://C:/Users/HP/Downloads/kinerja\%20kementerian\%20pertanian\%20\%202019.pdf

Kong, Ying. 2009. A Study on the Job Engagement of Company Employees. International Journal of Psychological Studies Vol. 1 No. 2 Desember 2009. China: Qufu Normal University.

Krishnamurty, J. dan Kumar, A. 2015. The Demographic Dividend: Challenges to Employment and Employability. Indian Journal of Labour Economics, 58 (1) p. 83-95.

Kusdiane, Soetarto, Sunito. 2018. Alih Fungsi Lahan dan Perubahan Masyarakat di Kecamatan Cimanuk, Kabupaten Pandeglang. Unpublished Paper. Sekolah Pasca Sarjana IPB: Bogor.

Lamb, et al. 2019. Lost and Found: Pathways from Disruption to Employment. Brookfield Institute: Toronto.

Malik, N. 2013. Dinamika Pasar Tenaga Kerja Indonesia. UMM Press: Malang.

McConnel, C. R, et al. 2015. Contemporary Labor Economics. Eleventh Edition. McGrawHill Education.

Mok and Qian. 2018. Massification of Higher Education and Youth Transition: Skills Mismatch, Informal Sector Jobs and Implications for China. Journal of Education and Work. ISSN 1363-9080.

Nilsson, B. 2018. The School-to-work Transition in Developing Countries. Journal of Development Studies Université Paris-Dauphine, PSL Research University. Paris: France.

Ngo, Q T. 2018. Individual-Level Employment Transitions in Rural Viet Nam. United Nations University World Institute for Development Economics Research. Helsinki: UNU-WIDER.

Núñez, A P V. 2017. Analysis of Formal-Informal Transitions in the Ecuadorian Labour Market. CEPAL Review No. 123. [online] https://repositorio.cepal.org/handle/11362/43454 (Diakses pada tanggal 19 Oktober 2019)

Nurdany dan Kresnowati. 2019. Digital-related Economy Sectors and Regional Economy Disruption. Jurnal Ekonomi dan Bisnis, 22 (1), p. 147-162.

Parray, et al. 2017. Indonesia Jobs Outlook 2017: Harnessing Technology for Growth and Job Creation. International Labour Organization.

Pramudiana, I D. 2017. Dampak Konversi Lahan Pertanian terhadap Kondisi Sosial Ekonomi Petani di Kecamatan Tikung Kabupaten Lamongan. Asketik, 1 (2), p. 63-71.

Rachman, L M. 2019. Transformasi Struktural Tenaga Kerja Pertanian Indonesia Berbasis Modernisasi Pertanian menuju Pertumbuhan Inklusif. Paper: Indonesia Development 
Intan, Pudjihardjo, Devanto. Transisi Penyerapan Tenaga Kerja Sektoral...

Forum 2019. [online] https://indonesiadevelopmentforum.com/2019/knowledgecenter/detail/12671-12671-transformasi-struktural-tenaga-kerja-pertanian-indonesiaberbasis-modernisasi-pertanian-menuju-pertumbuhan-inklusif?1571890821 Diakses pada tanggal 24 Oktober 2019.

Rada, Codrina dan Arnim, Rudiger von. 2012. Structural Transformation in China and India: A note on Macroeconomic Policies. Journal of Strucural Change and Economic Dynamics 23 (2012) 264-275. http://dx.doi.org/10.1016/j.strueco.2012.03.006 Diakses tanggal 5 Agustus 2019

Rastogi, P. N. 2002. Knowledge Management and Intellectual Capital as a Paradigm of Value Creation. Human Systems Management, 21(4). 229-240.

Suryahadi, A, Marshan J N, Indrio V T. 2018. Structural Transformation and the Release of Labor from Agriculture. Metro Manila: Asian Development Bank.

Todaro, Michael P, dan Smith, Stephen C. 2006. Pembangunan Ekonomi: Edisi Kesembilan, Jilid I. Jakarta: Erlangga.

Todaro, Michael P. 2000. Pembangunan Ekonomi Di Dunia Ketiga. Alih Bahasa: Aminuddin dan Drs. Mursid. Jakarta: Erlangga. 